\title{
Does Financial Instability of Conventional Banks Affect Financial Stability of Islamic Banks in GCC Countries?
}

\author{
Hamid Abdulkhaleq Hasan Al-Wesabi ${ }^{1} \&$ Rosylin Mohd. Yusof ${ }^{1}$ \\ ${ }^{1}$ Islamic Business School (IBS), University Utara Malaysia, Sintok, Kedah, Malaysia \\ Correspondence: Hamid Abdulkhaleq Hasan Al-Wesabi, Islamic Business School (IBS), University Utara Malaysia, \\ Sintok, Kedah, Malaysia.
}

Received: October 11, 2019

Accepted: November 16, 2019

Online Published: November 26, 2019

doi:10.5430/ijfr.v11n1p361

URL: https://doi.org/10.5430/ijfr.v11n1p361

\begin{abstract}
Purpose: The main purpose of this paper is to investigate the relationship between financial stability in Islamic banks and financial stability and soundness in conventional banks for five GCC countries.

Design/methodology/approach: By using time series data, this study employs Pedroni's panel cointegration to test the long-run relationship between financial stability of Islamic banks and financial stability of conventional banks in GCC countries during the period of (2000-2017). Besides, the study also employs Granger causality to test the causal link between stability of two types of banks (Islamic and Conventional). As well as employing Generalized Least Squares (GLS) to examine the effects between independent variables which are financial stability of conventional banks and their profitability, impact of period of financial crisis (2008/2009), oil prices fluctuations, banking concentration and financial sector development and financial stability of Islamic banks (as the dependent variable).

Findings: The findings of this research suggest that there is a long-run, significant and positive relationship between the financial stability of conventional banks and its Islamic counterpart. At the same time, the financial stability of conventional banks is found to Granger caused the stability of Islamic banks.

Originality/value: The results of the study contribute towards understanding the determinants of the financial stability of both Islamic banks and conventional banks and how they affect each other. This is important for policy ramifications by the Central Banks in GCC in terms of treating both types of banks differently to mitigate against future financial crises.
\end{abstract}

Keywords: financial stability of conventional and Islamic banks, Pedroni's panel cointegration test, Granger causality test, Generalized Least Squares (GLS), GCC countries

\section{Introduction}

Financial stability of an institution in a financial system of a country has become a challenge in light of significant changes in the entire economy, the financial system, and within the institution itself. The concept of 'financial stability' generally came about in the last decade to indicate the importance of the main functions of financial authorities led by Central Banks (Allen \& Wood, 2006). Banks' stability - whether Islamic banks (IBs henceforth) or conventional banks (CBs henceforth) - has been defined by Miah, M. D., and Uddin, H. (2017) as However, the best is to define financial stability of banks as the period when the instability of banks is absence (Allen \& Wood, 2006). However, Iqbal, Mirakhor, Krichenne, and Askari (2010) opined that financial stability is an accounting concept, representing the concept of solvency or equilibrium. It means that financial stability is described by the position of the liquid treasury, which shows whether the use of funds exceeds the sources of funds to be covered internally at abnormal times or during financial crises.

The global financial crisis is a lesson for bankers to be more cautious in the future, as no bank was immune to this crisis. During the financial crisis (2008/2009), many CBs suffered bank runs and announced bankruptcy, but no Islamic bank went bankrupt (Ghassan, Fachin, \& Guendoz, 2012). Nevertheless, that does not mean that IBs are immune to financial crises; they are affected, even indirectly influenced by the adverse impacts of the financial crises. One of these effects was the fall in oil prices, which mainly affected the IBs of Gulf Cooperation Council (GCC) (Zarrouk, 2012). Thus, this paper attempts to explore the impact of conventional bank instability, also its profitability on the financial stability of IBs and the financial soundness in GCC countries in the long run. 
GCC countries are chosen because they have a dual banking system, and the presence of IBs in GCC countries became more prominent, with more than 25\% market share out of all GCC Banks' total assets. For example, IBs in all Middle East and North Africa (MENA) countries have only 14\% market share out of all total assets of MENA banks (Basu, Prasad, \& Rodriguez, 2015). Given the prominence of Islamic banking presence in the GCC counties and operating in parallel with their conventional counterparts, it is therefore imperative to assess whether the financial stability of CBs does indeed affect the financial stability of IBs. Understanding this causal effect will help the Central Banks to design policies to affect IBs and CBs differently to mitigate against future financial crises. That would be the first motivation of this study, and the second is to clarify the importance of banking institutions to the economy as banks play the primary role in financial intermediation which is to allocate surplus funds or deposits from surplus units, savers or lenders, then effectively and efficiently support deficit units, borrowers or investors. That could be allocated physical capital in the economy in order to run the projects and enhance business development and trade in the economy and financial system (Allen \& Carletti, 2008). However, Islamic bank has an essential difference from the conventional bank that is the prohibition of interest on loans and deposits because Islamic bank follows the principals of Islamic law (sharia). This difference may reflect on the stability of each type of bank to affect the stability of another type.

\section{Literature Review}

Empirical studies conducted on individual bank's stability focus more on the impact of financial stability or its financial soundness. For example, these studies highlighted the comparison between the financial stability of large and small IBs and CBs. However, the comparison between the financial stability and financial soundness of two types of banks, i.e., both IBs and CBs, is still limited. This current study adopts IBs stability as the dependent variable (measured by Z-score index) and the independent variables as determinants of IBs stability. The most crucial determinant that this paper attempts to explore is the impact of the instability of CBs (measured by Z-score index) on the stability of IBs.

By reviewing the literature of financial stability, studies of bank's stability used to divide each type of bank based on its size into small and large banks. For instance, Čihák and Hesse $(2008 ; 2010)$ opined that the size of the bank must be taken into account just in order to perform a comparison between the stability of IBs and that of the conventional ones. Čihák and Hesse $(2008 ; 2010)$ further found that large IBs are riskier than small IBs where they are more stable than their counterparts from CBs. This is well supported by the studies of Shahid and Abbas (2012), and Abedifar, Molyneux, and Tarazi (2013), which assert that large IBs are riskier than small ones where they are more stable than large CBs. As well, large CBs are riskier than the small ones, these also the same findings of Shahid and Abbas (2012), and Abedifar, Molyneux, and Tarazi (2013).

However, Hasan and Dridi (2010) found that IBs performed better in terms of performance compared to the CBs during the financial crisis, and thus they were contributing to financial stability. Meanwhile, Gamaginta and Rokhim (2009) found that IBs are less stable than CBs. However, it is also found that IBs are better capitalized with higher intermediation ratio and higher asset quality, even though they are less cost-effective than the CBs, which perhaps make IBs better stock performance during financial crisis 2008/2009 (Beck, Demirguc-Kunt, \& Merrouche, 2013). It is also reported that during the crisis, IBs withstood better than CBs as not a single Islamic bank was declared bankrupt, unlike the CBs (Ghassan, Fachin, \& Guendoz, 2013). Notwithstanding the above success story of IBs, the IBs are also found to not insulated against the adverse impact of that crisis as they could also be affected by the indirect impacts of the crises (Ali, 2012).

Acknowledging the on-going debate comparing the stability of both CBs and IBs, this current paper attempts to go beyond this debate to focus more on the effects of the financial stability of IBs on the CBs and vice-versa. In doing so, three categories of variables have been chosen to examine the impact on IBs stability. Specific to bank variables are financial stability of CBs and their profitability, which represented by return on CBs' assets (ROA). For the industry of banking system variables: the competition between banks in the banking system and financial sector development. Moreover, macroeconomic variables are also two variables: first, global financial crisis period, which was selected as a dummy variable which takes one for years 2008-2009 and zero otherwise, and second, oil price fluctuations as an essential variable in the GCC countries.

Fluctuations in oil prices in GCC countries are one of the critical factors that could influence banks' financial soundness. As reported by International Monetary Fund (IMF) (2015) there is a link between economic growth and revenues of oil exports which means that a rise in oil price leads to a more significant government expenditure and a stronger fiscal position which in turn leads to a rise in corporate profitability and strengthen the balance sheets of banks (Callen, Khandelwal, Miyajima, \& Santos, 2015). Accordingly, the dropping in oil revenue could be a 
significant risk that determines credit default, which harms banks' solvency and adversely affects the real economy (Khandelwal, Miyajima, \& Santos, 2016). So, financial soundness is more affected by oil price shocks compared to the impact of just an increase in oil price. As in general financial performance is linked to oil price fluctuations in oil-rich economies, such as in GCC countries (Al-Khazali \& Mirzaei, 2017). It is therefore imperative that these countries, like the ones in GCC to be more diversified in terms of managing their economies rather than depending on just on oil sector revenues (Mehrara, 2008).

Besides oil price movements, many studies have also provided evidence that financial stability is adversely affected by the Global Financial Crisis (GFC) with varying impacts across countries and periods for both CBs and IBs (Fu, Lin, \& Molyneux, 2014; Ghosh, 2014). For example, IBs were better capitalized with higher ratios of asset quality and more cost-effective (Beck et al., 2013). Furthermore, Beck et al. (2013) also assert that profit-loss sharing (PLS) modes that are adopted by IBs make them more resilient against this crisis than CBs (Abduh, Omar, \& Duasa, 2011). However, some studies, such as Bourkhis and Nabi (2013), indicated that there is no significant difference in the stability of CBs and IBs, which are affected similarly due to the financial crisis in 2008.

From the industry-specific of the banking system, the degree of competition between banks is considered as an essential determinant of bank fragility and generally measured by concentration ratio (Note 1) (Al-Khouri \& Arouri, 2016). One of the most commonly used measures, that have been adopted to measure banking concentration is the Herfindahl-Hirschman index (Note 2) (HHI), which ranges from 0 (i.e., zero is represented minimum concentration or maximum competition) to 10,000 (i.e., 10,000 is represented maximum concentration or minimum competition). HHI is found to be significantly and negatively related to financial stability, therefore, the higher the banking concentration, the lesser will be the competition, and the lower will be the degree of financial stability (Čihák \& Hesse, 2010; Ghassan et al., 2013).

Another variable that represents banking industry efficiency is financial sector development. Thus it may impact bank performance, as it is measured by the ratio of bank credit to the private sector divided by Gross Domestic Product (GDP) (Bongini, Iwanicz-Drozdowska, Smaga, \& Witkowski, 2017), the financial sector development in some less developed countries, may enhance bank efficiency and performance. However, results from other studies indicated otherwise. For instance, the studies allude that more significant development of the financial sector could also create more competition, which may adversely impact the profitability of banks (Growe, DeBruine, Lee, \& Maldonado, 2014).

Generally, financial stability of a bank is defined as the period of bank instability absence (Allen \& Wood, 2006). As indicated, the financial instability of banks could be due to insolvency risk that can be hurt the economy as what happened during financial crises (Fethi \& Pasiouras, 2010). Therefore, instability and insolvency of the conventional bank may have an impact on Islamic bank stability. Conventional bank's instability has also been measured by the Z-score index, (ROA plus ratio of capital (or TE=total equity to total asset (TA), divided by standard deviation of ROA) as a common measure used by many studies (Beck et al., 2013; M. Čihák \& Hesse, 2008; Martin Čihák \& Hesse, 2010; Fu et al., 2014; Ghassan et al., 2013; Ghosh, 2014). Nevertheless, the recent study of Clark et al. (2018) who have used a new approach of the Z-score formula (as shown in 1), which is produced by Mare et al. (2017). Mare et al. (2017) criticized all previous approaches of Z-score index as they are deemed to be less effective. Against this backdrop, this paper will follow Clark et al. (2018), who adopted the following formula:

$$
Z_{i, t}=\frac{\mu_{R O A, t}+T E / T A_{i, T}}{\sigma_{R O A, t}} \text { with } t \in\{1,2, \ldots, T\}
$$

Where: $\mu_{R O A, t}$ : the moving mean ROA, period $\mathrm{t}$ : the current period. Meanwhile, the profitability of CBs, as represented by the return on assets of CBs (ROA_CB), is another important variable that may influence the stability of IBs. Many of researches that study the comparison between IBs, and CBs based on ROA found that there is an impact on Islamic bank's stability (Alturai \& Ki, 2013; Siraj \& Pillai, 2012; Toumi, Viviani, \& Belkacem, 2011; Youssef \& Samir, 2015). Thus, this present paper seeks to also examine the effects of ROA_CB on IBs' stability empirically, besides the impact of financial stability of CBs (Z-score index of CBs (ZSC_CB)) on the financial stability of IBs (Z-score index of IBs (ZSC_IB)). Yuksel (2017) tried to identify the relationship between IBs and $\mathrm{CBs}$ in terms of term deposit rate by using Granger causality, and the result suggested that there is no clear significant relationship between both types of banks. However, Chong and Liu (2009) affirmed that there is a 
significant causality from CBs to IBs. Similarly, Adeloba, Sulaiman, and Dhalan (2011) found one-way causality running from CBs to IBs. However, Kader and Leong (2008) found that there is bi-directional causality between IBs and CBs with regards to base lending rate and home financing, which means that type of bank matters.

Existing literatures also alluded that the type of banks, i.e., whether Islamic or conventional does not matter in terms of financial stability, which matters is the size of banks, as there is individual heterogeneity across banks due to difference in bank size. So, these studies used the total asset of a bank to categorize banks into large and small banks, as bank size has different effects on bank stability (Martin Čihák \& Hesse, 2010; Distinguin, Roulet, \& Tarazi, 2013; Ghassan et al., 2013). Therefore, this research also attempts to investigate whether the nature of the bank (Islamic or conventional) matters in order to capture the impact of financial stability running from CBs to the financial stability of IBs, or heterogeneity across banks matters more than Islamic or conventional nature of the banks. Understanding the nature of the relationship between macroeconomic variables, industry-specific variables, as well as the financial stability of CBs and IBs, are important to reduce the financial risks of IBs and CBs and mitigate against future financial instability.

\section{Data and Methodology}

\subsection{Theoretical Framework}

As mentioned above that the purpose of this research is to investigate whether the nature of the bank (Islamic or conventional) matters in order to capture the impact from the financial stability of CBs on the financial stability of IBs in the long run. Besides, this paper seeks to examine whether heterogeneity across banks matters for both Islamic and conventional nature of the bank. Therefore, an analysis of panel cointegration following Pedroni's $(1999,2004)$ method will be employed to allow for heterogeneity using coefficients of cointegration equation, and Granger causality.

It is hypothesized that there is a one-way causality from CBs to IBs in terms of financial stability. As shown in Figure 1, this research has taken into consideration two macroeconomic variables, such as the Global Financial Crisis Period (GFCP) and Oil Prices movements Risk (OPR). Moreover, two other variables from banking industry-specific as bank competition (HHI) and financial sector development (FSD), that could impact the stability of IBs. So, the data has been collected from the GCC region, from banking industry of each country, and individual banks, whether IBs or CBs. Therefore, data of variables that are related to CBs such as ZSC_CB and ROA_CB, averages of the series have been taken.

To analyze the relationship between stability of IBs and its conventional counterpart, and other independent variables, balanced panel data have been collected from data stream and bank scope data base for 34 banks (17 IBs and $17 \mathrm{CBs)}$ from 2000 to 2017 for five GCC countries excluded Oman which entered to Islamic banking industry just in 2012. So, function 2 expresses this relation, and panel model 3 explains the regression equation:

$$
Z S C_{I B}=f\left(G F C P, O P R, H H I, F S D, Z S C_{C B}, R O A_{C B}\right)
$$

And the model is:

$$
Z S C_{-} I B_{i t}=\beta_{0 i}+\beta_{1 \mathrm{i}} G F C P_{i t}+\beta_{2 i} O P R_{i t}+\beta_{3 i} H H I_{i t}+\beta_{4 i} F S D_{i t}+\beta_{5 i} Z S C_{-} C B_{i t}+\beta_{6 i} R O A_{-} C B_{i t}+\varepsilon_{i t}
$$

\begin{tabular}{|c|c|}
\hline Independent Variables & Dependent Variables \\
\hline GFCP & \multirow{6}{*}{ ZSC_IB } \\
\hline OPR & \\
\hline HHI & \\
\hline FSD & \\
\hline$\overline{\text { ZSC_CB }}$ & \\
\hline ROA_CB & \\
\hline
\end{tabular}

Figure 1. Theoretical framework

Where:

$Z S C_{-} I B_{i t}$ is Z-score index for Islamic bank (i) in year ( $\left.\mathrm{t}\right)$ 
$\beta_{0 i}$ : Constant coefficient,

$\beta_{\mathrm{ni}}=$ The slope coefficient and $1 \ldots \mathrm{n}$ : number of the variable,

$G F C P_{i t}$ : Global financial crisis period for the country (i) in year (t),

$O P R_{i t}$ : Oil prices risk exposure for the country (i) in year ( $\mathrm{t}$ ),

$H H I_{i t}$ : Banks concentration for the banking system of the country (i) in year ( $\mathrm{t}$ ),

$F S D_{i t}$ : Financial sector development for the banking system of the country (i) in year (t),

$Z S C_{-} C B_{i t}$ is the average of $\mathrm{Z}$-score index for conventional bank (i) in year ( $\mathrm{t}$ ),

$R O A_{-} C B_{i t}$ is the average of return on assets for conventional bank (i) in year $(\mathrm{t})$, and

$\varepsilon_{i t}$ : Term of the random error.

\subsection{The Panel Unit Root Test}

We start our analysis to test the presence of unit root (data stationarity) of each variable in time series data. It is crucial to test the order of the series or presence of unit root in the series in order to get an appropriate panel model (Musibau, Yusuf, \& Gold, 2019). Whereas, there are several tests usually used for this purpose, such as Levin and Lin (1993), Hadri (2000), Levin, Lin, and Chu (LLC) (2002) and Im, Pesaran, and Shin (1997, 2003). Thus, this paper used the most common tests such as Levin et al. (LLC) (2002) and Im, Pesaran, and Shin $(1997,2003)$ as also considered the two recent unit root tests (Annala \& Chen, 2011). According to Musibau et al. (2019), the main hypothesis of panel unit root as established in LLC is as shown in equation (4).

$$
\Delta Y_{t}=\alpha+\lambda t+\gamma Y_{t-1}+\sum_{i=1}^{k} \beta_{i} \Delta Y_{t-i}+\varepsilon_{t}
$$

The variable $Y_{t}$ represents each variable included in this research. In addition to important to check the presence of unit root in time series data, the Pedroni cointegration is also useful to solve the heterogeneity issues and to control the bias of country size (Syed Ali, 2017). In order to examine stationarity of data using unit root tests, the above tests will be implemented using a confidence level of 5\% to examine null and alternative hypotheses H0: Data are non-stationary (or it has a unit root) and H1: Data are stationary (or it has no unit root)

\subsection{The Panel Cointegration Test}

Two groups of tests for panel cointegration were recommended by Pedroni (1999, 2004). First, panel tests within dimension based and include four statistics (Note 3), which essentially pool the coefficients of autoregressive and consider the heterogeneity across banks and common time factors. Second, tests based on the between dimension approach, which includes three groups of statistics (Note 4), which are based on averages of individual autoregressive coefficients associated with the tests of data stationarity or unit root of the residual for each bank in the panel of time series. Pedroni (2004) documented an approach that can overcome the problem of implementing panel data with small samples while allowing heterogeneity for slopes $\left(\beta_{n}\right)$ and intercepts $\left(\beta_{0}\right)$ of the equation of cointegration (Mohd. Yusof \& Bahlous, 2013; Sapuan, 2013).

The seven tests of Pedroni are based on residuals that estimated, as shown in the long run model (5) as follows:

$$
y_{i t}=\alpha_{i}+\sum_{j=1}^{m} \beta_{j i} x_{j i t}+\varepsilon_{i t}
$$

Where: ${ }_{i t}=\rho_{i} \varepsilon_{i(t-1)}+w_{i t}$ are the residuals that estimated from the panel regression. So, Pedroni $(1999,2004)$ will be employed by this research to incorporate heterogeneity using Pedroni's panel cointegration test, which allows for cross-section effects of individual banks with heterogeneous intercept and slopes of cointegration equation to be tested, as well as to overcome the problem of the small sample.

\subsection{Granger Causality}

Granger causality is a common method that is used to examine the causal links between variables, and its mathematical processes are based on the model of linear regression. Test of Granger causality, which suggested by 
Granger (1969), has become an important issue in econometrics. It is based on the concept of 'precedence' that clarify a relationship among variables (Chen, 2006). Simply, Granger causality can be explained as a follow: if a single variable $A_{1}$ Granger causes another variable $A_{2}$, then the past values of $A_{1}$ may contain some information that helps predict the $A_{2}$, in addition to the information already contained in past values of $A_{2}$ separately (Granger, 1969). As mentioned above that Granger causality is employed by this research to check whether a time series of financial stability of CBs can be useful in forecasting the stability of IBs.

\subsection{Generalized Least Squares (GLS)}

Despite the presence of long-run relationships that can be tested by using the method of Pedroni's panel cointegration, this method could not provide the estimation of coefficient (Shaukat, Hasan, \& Alhabshi, 2014). So, for the coefficients' estimation, a feasible generalized least squares (GLS) analysis is proposed because of the form of heteroskedasticity, which may be a misidentification. Thus, this paper used the GLS to test the relationships; such estimation is considered a more powerful test and its results more efficient than ordinary least squares (OLS). As well as to solve problems of serial correlation and heteroskedasticity (Baltagi \& Wu, 1999; Hansen, 2007; Miller \& Startz, 2018).

Finally, to test whether there is cointegration, we need to accept or to reject the null hypothesis of no cointegration, $\left(H_{0}: \rho_{i}=1\right.$ for all $\left.i\right)$ against the alternative of the existence of cointegration, in the within-dimension $\left(\mathrm{H}_{\mathrm{A}}: \rho_{\mathrm{i}}=\rho<\right.$ 1 for all $i$ ) but for the between-dimension statistics $\left(\mathrm{H}_{\mathrm{A}}: \rho_{\mathrm{i}}<1\right.$ for all $\left.i\right)$ (Fowowe, 2011). So, the two hypotheses are presented as $H_{0}$ : No cointegration, and $\mathrm{H}_{\mathrm{A}}$ : Cointegration exists.

\section{Results}

Panel unit root tests are conducted for each variable as a requirement for panel cointegration. We start by running the tests of Levin et al. (LLC) (2002) and Im, Pesaran, and Shin $(1997,2003)$ as the two recent and common unit root tests (Annala \& Chen, 2011). As shown in Table 1 test of data stationarity at the level I(0), FSD has a unit root, as well as OPR has a unit root according to IPS tests. Thus, unit root tests at first difference I(1) must be run to check data stationarity, which is required for analyzing using the panel cointegration test.

Table 1. Unit root tests (at level)

\begin{tabular}{|c|c|c|c|}
\hline \multicolumn{4}{|c|}{$H_{0}$ : variable have a unit root or variable is non-stationary } \\
\hline Variables & LLC & IPS & Decision \\
\hline OPR & $-1.80692[0.0354] * *$ & $0.14665[0.5583]$ & Inconclusive \\
\hline GFCP & No result & $-4.00270 \quad[0.0000] *$ & Inconclusive \\
\hline HHI & $-21.8686[0.0000] *$ & $-17.2603[0.0000] *$ & Reject $H_{0}$ \\
\hline FSD & $-0.28972 \quad[0.3860]$ & $2.39283[0.9916]$ & Do not reject $H_{0}$ \\
\hline ROA_CB & $-8.65438[0.0000] *$ & $-5.90738[0.0000] *$ & Reject $H_{0}$ \\
\hline ZSC_CB & {$[0.0000] *$} & $-4.80687[0.0000]^{*}$ & Reject $H_{0}$ \\
\hline$\overline{\text { ZSC_IB }}$ & $-3.53092[0.0002] *$ & {$[0.0383]^{* *}$} & Reject $H_{0}$ \\
\hline
\end{tabular}

Note: * Indicate to the significance level at the $1 \%, * *$ Indicate to the significance level at $5 \%$.

As shown in Table 2, tests of unit root results on the first differences I(1) for all variables are significant at the $1 \%$ level of significance, which is to reject the non-stationary hypothesis and accept the alternative hypothesis of no unit root and data are stationary. 
Table 2. Unit root tests (at first difference)

\begin{tabular}{|c|c|c|c|}
\hline \multicolumn{4}{|c|}{$H_{0}$ : variable have a unit root or variable is non-stationary } \\
\hline Variables & LLC & IPS & Decision \\
\hline OPR & $-10.5935[0.0000]$ & $-6.97721 \quad[0.0000]$ & Reject $H_{0}$ \\
\hline GFCP & $-15.0676[0.0000]$ & $-11.2342[0.0000]$ & Reject $H_{0}$ \\
\hline HHI & $-25.2806 \quad[0.0000]$ & $-13.8146[0.0000]$ & Reject $H_{0}$ \\
\hline FSD & $-6.46284[0.0000]$ & $-8.95593[0.0000]$ & Reject $H_{0}$ \\
\hline ROA_CB & $-13.8347 \quad[0.0000]$ & $-9.59270[0.0000]$ & Reject $H_{0}$ \\
\hline ZSC_CB & $-18.8679[0.0000]$ & $-13.6864[0.0000]$ & Reject $H_{0}$ \\
\hline ZSC_IB & $-10.2535[0.0000]$ & $-13.6864[0.0000]$ & Reject $H_{0}$ \\
\hline
\end{tabular}

Note: All results of unit root test of all variables in I(1) are significant at the $1 \%$ significance level.

Hence, all variables are I(1), then Pedroni's panel cointegration tests are eligible to be used for examining the presence of a long-run relationship between the financial stability of both CBs and IBs. As shown in Table 3, and according to Pedroni's tests based on three specifications: individual intercept, individual intercept and individual trend, and no intercept and trend for variables: ZSC_IB GFCP OPR HHI FSD ZSC_CB and ROA_CB. The result shows that the null hypothesis of no cointegration (at usually 0.05 level of significance) is rejected; instead, the alternative hypothesis is accepted. Thus, the presence of cointegration expresses that a long-run relationship between variables that are described as cointegrated variables. That means financial stability of IBs is cointegrated with OPR, GFCP, HHI, FSD, financial stability of conventional, and their profitability. As well as it is appeared by using Granger causality Table 4; as a result, the null hypothesis of ZSC_CB does not Granger cause ZSC_IB is rejected. So, it means that financial stability of CBs Granger causes its Islamic counterpart. The result is consistent with the study of Chong and Liu (2009) and Adeloba et al. (2011), which affirmed that there is a significant causality from CBs to IBs. However, it does not agree with the findings of Kader and Leong (2008), that there is bi-directional causality between IBs and CBs.

Table 3 Pedroni's panel cointegration tests

\begin{tabular}{lllllll}
\hline & Intercept & \multicolumn{3}{l}{ Intercept +Trend } & None \\
& Statistic & $\begin{array}{l}\text { Weighted } \\
\text { Statistic }\end{array}$ & Statistic & $\begin{array}{l}\text { Weighted } \\
\text { Statistic }\end{array}$ & Statistic & $\begin{array}{l}\text { Weighted } \\
\text { Statistic }\end{array}$ \\
\hline Panel v-Statistic & -0.7967 & -1.7410 & -2.1116 & -2.9892 & -0.6698 & -2.7973 \\
\hline Panel rho-Statistic & 2.3889 & 3.4456 & 3.060107 & 4.2683 & 1.7349 & 2.7062 \\
\hline Panel PP-Statistic & $-11.7969^{*}$ & $-10.7299^{*}$ & $-17.2678^{*}$ & $-18.0248^{*}$ & $-9.5713^{*}$ & $-3.9497^{*}$ \\
\hline Panel ADF-Statistic & $-4.6106^{*}$ & $-6.5323^{*}$ & $-6.4195^{*}$ & $-6.5003^{*}$ & $-9.2188^{*}$ & $-4.5633^{*}$ \\
\hline Group rho-Statistic & 5.0197 & & 5.6041 & & 4.1123 & \\
\hline Group PP-Statistic & $-12.5414^{*}$ & & $-21.0872^{*}$ & & $-7.9961^{*}$ & \\
\hline Group ADF-Statistic & $-5.9774^{*}$ & & $-8.2988^{*}$ & & $-7.1574^{*}$ & \\
\hline
\end{tabular}

Note: * Indicate to the significance level at the $1 \%$

Table 4. Granger causality test

\begin{tabular}{llll}
\hline Lags: 2Null Hypothesis: & Obs & F-Statistic & Prob. \\
\hline ZSC_CB does not Granger Cause ZSC_IB & 272 & 3.64027 & $0.0276^{* *}$ \\
ZSC_IB does not Granger Cause ZSC_CB & & 0.14355 & 0.8663
\end{tabular}

Note: ** Indicate to the significance level at $5 \%$. 
As mentioned, that GLS is proposed to be used by this research because of the heteroskedastic case and the serial correlation (Baltagi \& Wu, 1999; Miller \& Startz, 2018). As shown in Table 5 that the null hypothesis of homoscedasticity is rejected, meaning that the heteroscedasticity is present in the data. As well as the problem of serial correlation is existed in the data according to the results shown in Table 6 since we fail to reject the null hypothesis of no serial correlation.

Table 5. Heteroskedasticity test

\begin{tabular}{ll}
\hline Heteroskedasticity Test: ARCH & \\
\hline F-statistic: 4.124067 & Prob. F(1,303): $0.0432^{* *}$ \\
\hline Obs R-squared: 4.095545 & Prob. Chi-Square(1): $0.0430^{* *}$ \\
\hline
\end{tabular}

Note: ** Indicate to the significance level at the 5\%

Table 6. Serial correlation LM test

\begin{tabular}{ll}
\hline Breusch-Godfrey Serial Correlation LM Test: & \\
\hline F-statistic: 47.96412 & Prob. F(2,297): 0.0000* \\
\hline Obs R-squared: 74.70586 & Prob. Chi-Square(2): 0.0000* \\
\hline
\end{tabular}

Note: * Indicate to the significance level at the $1 \%$

The results of the coefficients' estimation using GLS procedures are shown in table (4.7). It is found that the financial stability of CBs has a positive and significant impact on the financial stability of IBs. This result supported the current result presented by Granger causality (ZSC_CB Granger Cause ZSC_IB) and other studies such as Chong and Liu (2009) and Adeloba et al. (2011). Also, financial sector development was significantly and positively related to IBs' stability. This result supports the result of Bongini et al. (2017), and it is opposite from results of Growe et al. (2014). While, financial crisis period, oil price volatility risk, and profitability of CBs have a negative impact, even though they have not a significant impact on financial stability of IBs. The proxy of banking concentration variable (HHI) has no significant effect on the financial stability of IBs. Such results in line with some studies in the literature of banking concentration proxied by HHI (Chen, Wu, Jeon, \& Wang, 2017; İskenderoğlu \& Tomak, 2013). Even though in our study, there is a positive relationship between HHI and stability of IBs.

Table 7. Cross-sectional time-series FGLS regression

\begin{tabular}{|c|c|c|c|c|c|c|}
\hline \multicolumn{7}{|c|}{ Coefficients: generalized least squares } \\
\hline \multicolumn{7}{|c|}{ Panels: homoskedastic } \\
\hline \multicolumn{7}{|c|}{ Correlation: no autocorrelation } \\
\hline \multicolumn{7}{|c|}{ Estimated covariances $=1 ;$ Number of obs $=306$} \\
\hline \multicolumn{7}{|c|}{ Estimated autocorrelations $=0 ;$ Number of groups $=17$} \\
\hline \multicolumn{7}{|c|}{ Estimated coefficients $=7 ;$ Time periods $=18 ;$ Wald chi $2(6)=23.97$} \\
\hline \multicolumn{7}{|c|}{ Log likelihood $=-1287.01 ;$ Prob $>$ chi $2=0.0005$} \\
\hline zsc_ib & Coef. & Std. Err. & $\mathrm{Z}$ & $\mathrm{P}>|\mathrm{z}|$ & {$[95 \%$ Conf } & val] \\
\hline gfcp & -2.124008 & 5.478441 & -0.39 & 0.698 & -12.86156 & 8.613539 \\
\hline opr & -7.627165 & 4.979523 & -1.53 & 0.126 & -17.38685 & 2.13252 \\
\hline hhi & .1247089 & 5.208361 & 0.02 & 0.981 & -10.08349 & 10.33291 \\
\hline fsd & .1728518 & .0597517 & 2.89 & $0.004 *$ & .0557407 & .2899629 \\
\hline zsc_cb & .508683 & .1965062 & 2.59 & $0.010^{*}$ & .1235379 & .8938282 \\
\hline roa_cb & -.053362 & 1.207102 & -0.04 & 0.965 & -2.419238 & 2.312514 \\
\hline cons & 7.103418 & 20.69283 & 0.34 & 0.731 & -33.45377 & 47.66061 \\
\hline
\end{tabular}

Note: * Indicate to the significance level at the $1 \%$ 


\section{Discussion and Conclusion}

This paper attempts to examine the impact of financial stability of CBs and their profits on the financial stability of IBs located in 5 countries, which are GCC countries between 2000 and 2017. In addition to some other variables such as the impact of the period of the financial crisis (2008), oil price fluctuations, banking concentration, and financial sector development, Pedroni's panel cointegration test is performed to estimate the long-run relationship among the variables. The unit root test is found that all variables became stationary at the first difference, and that is considered as a prerequisite to use panel cointegration test. This study follows Pedroni's method, which allows for heterogeneity in the coefficients of cointegration equation, as indicated that the heterogeneity of individual banks may matter more than the nature of the bank, whether Islamic or conventional (Ghassan et al., 2013).

The results of Pedroni's panel cointegration test indicated that the variables are cointegrated, meaning that there is a long-run relationship between variables. These results are supported by the Granger causality test, which indicated that the financial stability of CBs Granger causes the stability of IBs. These results consistent with Chong and Liu (2009) and Adeloba, Sulaiman, and Dhalan (2011) as they found a significant causality from CBs to IBs, as well as Kader and Leong (2008) found bi-directional causality between IBs and CBs regarding base lending rate.

As it is found that there is heteroskedasticity presence in the data as well as serial correlation, GLS was proposed to be used to examine the impact of GFCP, OPR, HHI, FSD, ZSC_CB, and ROA_CB on ZSC_IB. From findings, ZSC_CB has a significant positive relationship related to stability of IBs. However, ROA_CB has an insignificant negative relationship with stability of IBs. According to this finding, if CBs are not stable, the IBs will be not stable as well. Nevertheless, more profitability achieved by CBs will lead to less stability of IBs. This is important for policy ramifications by Central Banks in GCC countries regarding treating both types of banks differently to mitigate against the future financial crises.

For other variables, GFCP has a negative relationship related to the stability of IBs, even though it has an insignificant impact. Oil price fluctuations affect the financial stability of IBs insignificantly and negatively. Market concentration proxied by HHI has an insignificant and positive relationship, as it is insignificant so, it is opposite from the hypothesis of HHI that found already by some studies (Čihák \& Hesse, 2010; Ghassan et al., 2013). That means higher banking concentration (or lower competition) leads to higher stability of IBs. This result consistent with study of Srairi (2013), who used concentration ratio to measure banking concentration, as well study of Rajhi and Hassairi (2013), who found a positive relationship between HHI as a measurement of banking concentration and financial stability of large banks in Southeast Asian countries.

Finally, for the development of the financial sector, the result shows that it has a significant positive relationship related to the financial stability of IBs. Meaning that the more significant development of the financial sector leads to enhance bank efficiency and profitability, the same that found by Growe et al. (2014). As also summarized by IMF (2018) that the financial system in the GCC countries over the last decades has developed significantly. GCC banks and equity markets are supported by a booming sector of Islamic finance, a combination of buoyant economic activity, and the reforms of the financial sector. Further, development and inclusion of financial sector in GCC economies seem to be associated with stronger economic growth.

The main purpose of this study is to clarify the relationship between financial stability and soundness for two types of banks IBs and CBs. Thus, this study presents this contribution to the current literature via its result to prove that there is a long run, positive and significant relationship between stability of CBs and stability of IBs. Moreover, it is consistent with what has found using Granger causality that conventional bank stability determines its counterpart of IBs. So, regulators and policymakers in Central Banks of GCC should take into consideration the adverse influence of the conventional bank's instability on the stability of Islamic bank in the long run.

Future researches should add more relevant variables to this current model and/or use different measures and methodologies. Also, take into account this current model and attempt to examine how to develop the banking system as well as Islamic bank performance to be separated from the effects of instability of CBs. Hence, future researches should study more issues about the differentiation between IBs and CBs to enhancing rules and regulations in this regard.

\section{References}

Abduh, M., Omar, M. A., \& Duasa, J. (2011). The Impact of Crisis and Macroeconomic Variables towards Islamic Banking Deposits. American Journal of Applied Sciences, 8(12), 1378-1383. https://doi.org/10.3844/ajassp.2011.1378.1383

Abdul Kader, R., \& Yap, K. L. (2008). The impact of interest rate changes on Islamic bank financing. 
Abedifar, P., Molyneux, P., \& Tarazi, A. (2013). Risk in Islamic banking. Review of Finance, 17(6), 2035-2096.

Adebola, S. S., Yusoff, W. S. W., \& Dahalan, J. (2011). The impact of macroeconomic variables on Islamic banks financing in Malaysia. Research Journal of Finance and Accounting, 2(4), 22-32.

Ali, A. S. (2012). Islamic banking structures: Implications for risk and financial stability. Islamic Economic Studies, 20(2), 141-147.

Al-Khazali, O. M., \& Mirzaei, A. (2017). The impact of oil price movements on bank non-performing loans: Global evidence from oil-exporting countries. Emerging Markets Review, 31(2016), 193-208. https://doi.org/10.1016/j.ememar.2017.05.006

Al-Khouri, R., \& Arouri, H. (2016). The simultaneous estimation of credit growth, valuation, and stability of the Gulf Cooperation Council banking industry. Economic Systems, 40(3), 499-518. https://doi.org/10.1016/j.ecosys.2015.12.005

Allen, F., \& Carletti, E. (2008). The Roles of Banks in Financial Systems. https://doi.org/10.2139/ssrn.1268367

Allen, W. A., \& Wood, G. (2006). Defining and achieving financial stability. Journal of Financial Stability, 2(2), 152-172. https://doi.org/10.1016/j.jfs.2005.10.001

Alturai, E., \& Ki. (2013). Assessing Risk and Profitability of Islamic Banks: A Comparison Between Islamic and Conventional Banks in the Gulf Cooperation Council.

Annala, C. N., \& Chen, S. (2011). Convergence of state and local fiscal policies: an application of panel unit root tests. Journal of Economics and Economic Education Research, 12(1), 27.

Askari, H., Iqbal, Z., Krichene, N., \& Mirakhor, A. (2010). The Stability of Islamic Finance. https://doi.org/10.1002/9781118390450

Baltagi, B. H., \& Wu, P. X. (1999). Unequally spaced panel data regressions with AR (1) disturbances. Econometric Theory, 15(6), 814-823. https://doi.org/10.1017/S0266466699156020

Basu, R., Prasad, A., \& Rodriguez, S. (2015). Monetary Operations and Islamic Banking in the GCC: Challenges and Options. IMF Working Paper Middle. https://doi.org/10.5089/9781513588513.001

Beck, T., Demirguc-Kunt, A., \& Merrouche, O. (2013). Islamic vs. conventional banking: Business model, efficiency and stability. Journal of Banking and Finance, 37(2), 433-447. https://doi.org/10.1016/j.jbankfin.2012.09.016

Ben Ltaifa, N. (2018). How Developed and Inclusive are Financial Systems in the GCC?. Retrieved from www.imf.org

Bongini, P., Iwanicz-Drozdowska, M., Smaga, P., \& Witkowski, B. (2017). Financial development and economic growth: The role of foreign-owned banks in CESEE countries. Sustainability (Switzerland), 9(3), 1-25. https://doi.org/10.3390/su9030335

Bourkhis, K., \& Nabi, M. S. (2013). Islamic and conventional banks' soundness during the 2007-2008 financial crisis. Review of Financial Economics, 22(2), 68-77. https://doi.org/10.1016/j.rfe.2013.01.001

Callen, T., Khandelwal, P., Miyajima, K., \& Santos, A. (2015). Oil Prices, Financial Stability, and the Use of Countercyclical Macroprudential Policies in the GCC. Prepared for the Annual Meeting of Ministers of Finance and Central Bank Governors.

Chen, M., Wu, J., Jeon, B. N., \& Wang, R. (2017). Monetary policy and bank risk-taking: Evidence from emerging economies. Emerging Markets Review, 31, 116-140. https://doi.org/10.1016/j.ememar.2017.04.001

Chong, B. S., \& Liu, M.-H. (2009). Islamic banking: interest-free or interest-based? Pacific-Basin Finance Journal, 17(1), 125-144. https://doi.org/10.1016/j.pacfin.2007.12.003

Čihák, M., \& Hesse, H. (2008). Islamic Banks and Financial Stability: An Empirical Analysis. International Journal of Business and Commerce, 5(03), 64-87. https://doi.org/10.1007/s10693-010-0089-0

Čihák, M., \& Hesse, H. (2010). Islamic Banks and Financial Stability: An Empirical Analysis. Journal of Financial Services Research, 38(2), 95-113. https://doi.org/10.1007/s10693-010-0089-0

Clark, E., Mare, D. S., \& Radić, N. (2018). Cooperative banks: What do we know about competition and risk preferences?. Journal of International Financial Markets, Institutions and Money, 52, 90-101. https://doi.org/10.1016/j.intfin.2017.09.008 
Distinguin, I., Roulet, C., \& Tarazi, A. (2013). Bank regulatory capital and liquidity: Evidence from US and European publicly traded banks. Journal of Banking and Finance, 37(9), 3295-3317. https://doi.org/10.1016/j.jbankfin.2013.04.027

Fethi, M. D., \& Pasiouras, F. (2010). Assessing bank efficiency and performance with operational research and artificial intelligence techniques: A survey. European Journal of Operational Research, 204(2), 189-198. https://doi.org/10.1016/j.ejor.2009.08.003

Fowowe, B. (2011). The finance-growth nexus in Sub-Saharan Africa: Panel cointegration and causality tests. Journal of International Development, 23(2), 220-239. https://doi.org/10.1002/jid.1660

Fu, X. (Maggie), Lin, Y. (Rebecca), \& Molyneux, P. (2014). Bank competition and financial stability in Asia Pacific. Journal of Banking and Finance, 38(1), 64-77. https://doi.org/10.1016/j.jbankfin.2013.09.012

Gamaginta, \& Rokhim, R. (2009). The Stability Comparison between Islamic Banks and Conventional Banks: Evidence in Indonesia. 8th International Conference on Islamic Economics and Finance (pp. 1-29).

Ghassan, H. B., Fachin, S., \& Guendoz, A. a. (2012). Financial Stability of Islamic and Conventional Banks in Saudi Arabia: a Time Series Analysis (pp. 1-21).

Ghosh, S. (2014). Risk, capital and financial crisis: Evidence for GCC banks. Borsa Istanbul Review, 14(3), 145-157. https://doi.org/10.1016/j.bir.2014.06.003

Granger, C. W. (1969). Investigating causal relations by econometric models and cross-spectral methods. Econometrica: Journal of the Econometric Society, 424-438. https://doi.org/10.2307/1912791

Growe, G., DeBruine, M., Lee, J. Y., \& Maldonado, J. F. T. (2014). The Profitability and Performance Measurement of U.S. Regional Banks Using the Predictive Focus of the "Fundamental Analysis Research." Advances in Management Accounting, 24, 189-237. https://doi.org/10.1108/S1474-787120140000024006

Hadri, K. (2000). Testing for stationarity in heterogeneous panel data. The Econometrics Journal, 3(2), 148-161. https://doi.org/10.1111/1368-423X.00043

Hansen, C. B. (2007). Generalized least squares inference in panel and multilevel models with serial correlation and fixed effects. Journal of Econometrics, 140(2), 670-694. https://doi.org/10.1016/j.jeconom.2006.07.011

Im, K. S., Pesaran, M. H., \& Shin, Y. (1997). Testing for Unit Roots in Heterogeneous Panels. Mimeo, Department of Applied Economics, University of Cambridge.

Im, K. S., Pesaran, M. H., \& Shin, Y. (2003). Testing for unit roots in heterogeneous panels. Journal of Econometrics, 115(1), 53-74. https://doi.org/10.1016/S0304-4076(03)00092-7

Iskenderoglu, O., \& Tomak, S. (2013). Competition and stability: An analysis of the Turkish banking system. International Journal of Economics and Financial Issues, 3(3), 752-762.

Kammer, M. A., Norat, M. M., Pinon, M. M., Prasad, A., Towe, M. C. M., \& Zeidane, M. Z. (2015). Islamic finance: Opportunities, challenges, and policy options: IMF. https://doi.org/10.5089/9781498325035.006

Khandelwal, P., Miyajima, M. K., \& Santos, M. A. O. (2016). The impact of oil prices on the banking system in the GCC. International Monetary Fund. https://doi.org/10.5089/9781475523393.001

Levin, A., \& Lin, C.-F. (1993). Unit root tests in panel data: new results. Economics Working Paper Series, University of California at San Diego.

Levin, A., Lin, C.-F., \& Chu, C.-S. J. (2002). Unit root tests in panel data: asymptotic and finite-sample properties. Journal of Econometrics, 108(1), 1-24. https://doi.org/10.1016/S0304-4076(01)00098-7

Mare, D. S., Moreira, F., \& Rossi, R. (2017). Nonstationary Z-Score measures. European Journal of Operational Research, 260(1), 348-358. https://doi.org/10.1016/j.ejor.2016.12.001

Mehrara, M. (2008). The asymmetric relationship between oil revenues and economic activities: The case of oil-exporting countries. Energy Policy, 36(3), 1164-1168. https://doi.org/10.1016/j.enpol.2007.11.004

Miah, M. D., \& Uddin, H. (2017). Efficiency and stability: A comparative study between Islamic and conventional banks in GCC countries. Future Business Journal, 3(2), 172-185. https://doi.org/10.1016/j.fbj.2017.11.001

Miller, S., \& Startz, R. (2018). Feasible Generalized Least Squares Using Machine Learning. https://doi.org/10.2139/ssrn.2966194 
Musibau, H. O., Yusuf, A. H., \& Gold, K. L. (2019). Endogenous specification of foreign capital inflows, human capital development and economic growth: A study of pool mean group. International Journal of Social Economics. https://doi.org/10.1108/IJSE-04-2018-0168

Pedroni, P. (1999). Critical values for cointegration tests in heterogeneous panels with multiple regressors. Oxford Bulletin of Economics and Statistics, 61(S1), 653-670. https://doi.org/10.1111/1468-0084.61.s1.14

Pedroni, P. (2004). Panel cointegration: asymptotic and finite sample properties of pooled time series tests with an application to the PPP hypothesis. Econometric Theory, 20(3), 597-625. https://doi.org/10.1017/S0266466604203073

Rajhi, W. (2013). Islamic Banks and Financial Stability: A Comparative Empirical Analysis Between MENA and Southeast Asian Countries. Région et Développement, 37, 1-31. https://doi.org/10.2139/ssrn.2010126

Sapuan, N. (2013). A Panel Cointegration Analysis of Bank profitability and Bank-specific Variables in Islamic Banks. Proceedings of 3rd Asia-Pacific Business Research Conference 25-26 February 2013, 8(3/2013), 195-209. Kuala Lumpur, Malaysia. https://doi.org/10.1504/IJBGE.2013.057375

Shahid, M. A. (2012). Financial stability of Islamic banking in Pakistan: An empirical study. African Journal of Business Management, 6(10), 3706-3714. https://doi.org/10.5897/AJBM11.1306

Shaukat, M., Hasan, Z., \& Alhabshi, D. S. O. (2014). Financing Economic Growth with Stability from Islāmic Perspective. Journal of Islamic Business and Management, 219(2622), 1-48.

Siraj, K. K., \& Pillai, P. S. (2012). Comparative Study on Performance of Islamic Banks and Conventional Banks in GCC region. Journal of Applied Finance \& Banking, 2(3), 123-161.

Srairi, S. (2013). Ownership structure and risk-taking behaviour in conventional and Islamic banks: Evidence for MENA countries. Borsa Istanbul Review, 13(4), 115-127. https://doi.org/10.1016/j.bir.2013.10.010

Syed Ali, R. (2017). Impact of foreign capital inflows on economic growth in the presence of currency and banking crises. PhD Thesis, Universiti Utara Malaysia.

Toumi, K., Viviani, J.-L., \& Belkacem, L. (2011). A comparison of leverage and profitability between Islamic and conventional banks. 6th International Finance Conference on Financial Crisis and Governance (pp. 768-784). https://doi.org/10.2139/ssrn.1836871

Youssef, A., \& Samir, O. (2015). A Comparative Study on the Financial Performance between Islamic and Conventional Banks: Egypt case. International Journal of Business \& Economic Development, 3(3), 20.

Yuksel, S. (2017). The causality between returns of interest-based banks and Islamic banks: the case of Turkey. International Journal of Islamic and Middle Eastern Finance and Management, 10(4), 519-535. https://doi.org/10.1108/IMEFM-12-2013-0133

Yusof, R. M., \& Bahlous, M. (2013). Islamic banking and economic growth in GCC \& East Asia countries: A panel cointegration analysis. Journal of Islamic Accounting and Business Research, 4(2), 151-172. https://doi.org/10.1108/JIABR-07-2012-0044

Zarrouk. (2012). Does Financial Crisis Reduce Islamic Banks' Performance? Evidence from GCC Countries Zarrouk. Journal of Islamic Finance and Business Research, 1(1), 1-16.

\section{Notes}

Note 1. Concentration ratio is the sum of deposits (or assets) for three (some of the studies five) largest banks divided by the deposits (or the total assets) of all banks in the banking system.

Note 2. HHI is the sum of squared market shares of all banks using bank deposits (also, some studies have used bank's loans or bank's total assets.

Note 3. Panel v-statistic, panel PP-statistic, panel $\rho$-statistic, and panel ADF-statistic.

Note 4. Group $\rho$-statistic, group PP-statistic, and group ADF-statistic. 